\title{
SUSTAINABLE OF AGRICULTURAL DEVELOPMENT IN INDIAN ECONOMY
}

\author{
NITIN VINAYAK GAIKWAD \\ Assistant Professor, Bharati Vidyapeeth's Dr. Patangrao Kadam Mahavidyalaya, Sangli, India \\ *Corresponding Author: Dr. Nitin Vinayak Gaikwad: E Mail: nitinhira31@gmail.com \\ Received $10^{\text {th }}$ June 2021; Revised 11 ${ }^{\text {th }}$ July 2021; Accepted $20^{\text {th }}$ Aug. 2021; Available online 15 ${ }^{\text {th }}$ Jan. 2022 \\ https://doi.org/10.31032/IJBPAS/2022/11.1.1025
}

\begin{abstract}
India is basically an agricultural country where people have relied solely on agriculture for a long time. In Indian economy agriculture activity is a major economic sector. Agriculture provides food, inputs and employment to the vast majority of the country's population. Economic development in the first phase of exports receives significant foreign exchange, which can be used to import large quantities for industrial development and infrastructure. The key to economic growth seems to lie in the development of the agricultural sector, which must be emphasized. Interdependence between the agricultural and nonagricultural sectors should be noted. In fact, the growth of your partnership between the agricultural and non-agricultural industries helps. The demand for non-agricultural inputs of industrial origin drives industrial activity. Industrial growth increases the demand for wages, goods and commodities that help increase agricultural employment and income. Rising agricultural revenue creates a market demand for industrial property. And agriculture contributes to the country's economy. Its contribution to the country's income is very low, but compared to developed economies it is large. In 1950-51 the contribution of the agricultural sector to India's national income was 56.10 per cent, now almost 15 per cent. The contribution to job creation is important in this sector, because in the nation as a whole about $60 \%$ of the population depends on agriculture and the related sectors. Agriculture provides food for 121 million people in India, and their contribution to market growth is significant.
\end{abstract}

Keywords: Mainstays, Sustainable, Phenomenon, Croplands, Green Revolution 


\section{INTRODUCTION}

Highly sustainable agriculture is defined as sustainable as any set of agricultural practices or processes that are most conducive to economic development, are environmentally safe and socially acceptable for their development. The agricultural use of the planting system requires significant input of leaking fertilizer into the groundwater pollution system, drinking equipment and remote coastal fisheries is a sustainable economic system as long-term supply of fertilizers is costly and economically viable. Chemical fertilizer is mostly, easily transported by portion of large grain production andit is not environmentally or socially sustainable, but not including the cost of environmental damages to the community or groups of families. The organic farming focuses on "living soil", adapting to the use of biological processes to avoid the use of synthetic chemicals and fertilizers. Sustainable agriculture advocates agree with the biological focus and expect to reduce the use of chemicals, but not in reality. Another term used in the context of sustainable agriculture is "alternative farming". Some farming practices are critical to enriching the performance characteristics of sustainable agriculture. The traditional farming methods used for irrigation, chemical fertilizers, pesticides and high yielding seeds are called conventional farming, due to the increasing use of chemical fertilizers and pesticides, conventional agriculture is a major source of inland water and coastal pollution. Criticism is placed on "external costs" that affect traditional agriculture, their impact on communities, the environment and human health.

Table 1: Percentage Share of Gross Domestic Product (GDP)

\begin{tabular}{|c|c|c|c|c|c|c|c|c|}
\hline Sector & $1950-51$ & $2014-15$ & $2015-16$ & $2016-17$ & $2017-18$ & $2018-19$ & $\begin{array}{c}2019-20 \\
(Q)\end{array}$ & $\begin{array}{c}2020-21 \\
(\text { RE) }\end{array}$ \\
\hline $\begin{array}{c}\text { Agriculture, } \\
\text { forestry \& } \\
\text { fishing }\end{array}$ & 55.8 & 19.0 & 18.3 & 17.4 & 16.80 & 15.7 & 14.6 & 14.3 \\
\hline Industry & 15.2 & 27.9 & 28.0 & 28.6 & 28.7 & 28.1 & 28.1 & 28.0 \\
\hline Service & 29.0 & 53.0 & 53.8 & 54.0 & 54.5 & 56.2 & 57.3 & 57.7 \\
\hline & 100 & 100 & 100 & 100 & 100 & 100 & 100 & 100 \\
\hline
\end{tabular}

\section{OBJECTIVES:}

A. The study of the Conceptual frameworks of sustainable, analyze the review of the literature with reference to India.

B. To study for the needs of sustainable of agriculture for in Indian economy.
C. To study the some recommendations for sustainable of agriculture sector.

\section{METHODOLOGY:}

The present study is descriptive and the data is obtained from secondary sources, i.e. collected from a various references, which already exist in the published or an unpublished form of the 
research article, based on review literature and methods including for collecting all available information research papers related to selecting relevant papers / books for review. The selection papers objective is based on their relevance and contribution to the main body of knowledge. The author attempts to make a preliminary reading of selected papers which will be the core of this review study.
NEED

FOR

\section{AGRICULTURE}

We can study and compare for the study of three broad types of farming i.e. traditional farming, conventional farming and modern farming (such as modern Green revolution and technologies), sustainable agriculture. We can compare the three dimensions - environmental, economic and social.

Table 2: The Public, Private Investment and Allied Sectors in total GDP at Market Prices (Rs. Crore)

\begin{tabular}{|c|c|c|c|c|c|c|c|}
\hline Year & $\begin{array}{c}\text { Public } \\
\text { Investment }\end{array}$ & $\begin{array}{c}\text { Private } \\
\text { Investment }\end{array}$ & Total & $\begin{array}{c}\text { GDP at } \\
\text { market price }\end{array}$ & \multicolumn{3}{|c|}{ Share (\%) in Total } \\
\hline & & & & & Public & Private & Total \\
\hline $2014-15$ & 16187 & 59909 & 76096 & 3242209 & 0.5 & 1.8 & 2.3 \\
\hline $2015-16$ & 19940 & 66671 & 86611 & 3544348 & 0.6 & 1.9 & 2.4 \\
\hline $2016-17$ & 22987 & 67723 & 90710 & 3872974 & 0.6 & 1.7 & 2.3 \\
\hline $2017-18$ & 23257 & 81777 & 105034 & 4253184 & 0.5 & 1.9 & 2.5 \\
\hline $2018-19$ & 22628 & 106031 & 128659 & 4462967 & 0.5 & 2.4 & 2.9 \\
\hline $2019-20$ & 23635 & 109742 & 133377 & 4869317 & 0.5 & 2.3 & 2.7 \\
\hline
\end{tabular}

Source: Central Statistical Office, New Delhi

\section{The Ecological sustainability}

The traditional farming methods are not environmentally sustainable for agriculture and allied agriculture activities, they overuse natural resources, reduce soil fertility, erode soil and contribute to global climate change. Sustainable agriculture has many advantages over traditional and non-traditional methods.

\section{A. Soil fertility:}

A. The fertile soil of fertility is a major problem in many parts of India. The sustainable agriculture improves various type fertility and the soil texture are prevents erosion, so it is to be the answer.

\section{B. Water:}

Water is irrigation is the biggest consumer and fertilizer and pesticides contaminate both surface- subsurface groundwater's. The sustainable agriculture is increases for the organic matter for agriculture to content of the top of soil, so raising it is ability to retain and store of water that falls in rain any region.

\section{Biodiversity:}

The existence of a variety of animals and plants that together create a good and healthy environment. The frequently involve mixed cropping of sustainable agricultural practices, Thus increasing the diversity of the crops produced and the diversity of insects and other animals and plants in and around the field.

\section{Pollution:}

The pollution is caused by the pesticides is 
harmful to human health as well as the local environment. In proper handling, storage and use of pesticides for lead to the health of pollution problems. The sustainable agriculture are reduces to the eliminates for the use of hazardous of chemicals to instead it controls pests to the use of various biological and agricultural remedies and natural substances.

\section{E. Landscape:}

In agriculture and forestry are makes up the rural landscapes improper use for leads to erosion, landslides and floods, closes irrigation for canals and reduces to the ability of land and support for the local population as well. The poor of rural people come from to the cities of search of jobs. The creating ugly, unsanitary slums and that for further destroy of the landscape. The rehabilitating of environmentally for degraded areas of requires huge investments as such for that some countries can afford for the landscape. The sustainable agriculture avoids for these problems can by improving for productivity for conserving soil as well avoiding agricultural expansion for the unsuitable areas, and saving rural employment.

\section{F. Climate:}

While climate factors have the greatest impact on or depend on agriculture, practice has made a significant contribution to global climate change. Climate affects agriculture, and conventional agriculture contributes to the production of greenhouse gases through a variety of climatic factors that reduce the amount of carbon stored in soil and plants, the production of methane and energy-intensive activity in agricultural horticultural areas. Such as the production of synthetic fertilizers. Adopting sustainable agriculture will significantly reduce these effects.

\section{The Economic sustainability}

The agriculture is cannot be sustainable for unless it is the financially viable or long-term. of the traditional farming and outweighs to the long-term economic for risks of "sustainable" alternatives.

\section{A. Export vs. local orientation:}

The Government is lead tends to place or more importance for an export-oriented manufacturing systems than on domestic demand it is misleading. The focusing on exports alone are involves hidden costs transportation or local food security guarantees etc. The policies are equally important for a balanced trade and balance between domestic and demand of food security in particular area or region.

\section{B. Debt:}

The Green Revolution was launched to significantly increase grain and production in India, but a large number of small farmers got stuck in debt or trap because they borrowed to 
increase their production and then found themselves unable to pay. Money, back about 40,000 was so desperate that he committed suicide.

\section{Risk:}

The focusing on the specific items leads for the higher financial returns of there are some risks in market production, markets are changing rapidly and the international agricultural prices are falling. The cheap foreign food can enter. National market, without market to Indian farmers. With the signing of the WTO, India is under pressure to deregulate the government and open up its economy to the world market, so it cannot protect its farmers behind the tariff walls.

\section{The Niche markets:}

Primarily organic farming is important for the strengthening of any ecological and sustainable route to agriculture. Demand for this specialty has grown significantly as a result of recent corporate scandals.

\section{E. Employment:}

The agriculture farming is the main source of the rural employment. The trends towards for the specialization and mechanization of they may be increase for narrowly measured of "efficiency", but they are reduce for the employment on the land. The welfare of costs for the unemployment can must to be taken into the account for it, when designing the national agricultural support for programmers. The sustainable agriculture can use, with its emphasis on the small-scale or labour-intensive activities and helps overcome to these problems.

\section{Social sustainability}

The farming techniques are social as well sustainability for the related to the field ideas of the social and acceptability and justice.

\section{A. Inclusiveness:}

In the development of cannot be sustainable for the without of reducing for the poverty of the masses in the India. The government must to find ways to the benefit of the rural poor and through agricultural development of the region.

\section{B. Political unrest:}

The gaps in the between the "haves" and "havenots" feed for feeling of the social injustice and among for those who have to feel neglected and the excluded from development of opportunities, as well as the better-off sympathizers. The result is a climate for favorable for political and opposition as even violence.

\section{Local acceptance:}

In many the new technologies is based on practices or the assumptions from outside because they are failing. Local social customs, traditions, norms and prohibited the sustainable agricultural practices usually are based on it, so locals are more likely for the accept and adapt 
to their own needs.

\section{Indigenous knowledge:}

The sustainable farming is practices often rely on the traditional information of local innovation. The local knowledge and about for their environment, the crops and livestock, they keep locally for adapted varieties and crop for varieties. They have social and structures of the manage and protect for common resources, help to those in need, for maintain in the social fabric. Instead of ignoring or replacing for this knowledge, sustainable agricultural and development seeks to build on the enrich it with the right information from the outside.

\section{E. Gender:}

The traditional agriculture is largely dependend for the women traditionally and bear for the heaviest burden in terms of the wages. Men also benefit for the most from modern and traditional farming, they control what is the grown and how the resulting are income for spent. The sustainable agriculture seeks to ensure that the burdens and benefits are the shared more equally and between men and women.

\section{F. Food security:}

The traditional farming is to techniques often to fail for the produce of enough food or enough variety for a balanced diets. The traditional and modern agriculture focuses on the few things so people are still do not get a balanced diet. The sustainable agriculture improves for food security and by improving the food quality and nutritional value of producing for wide range of the products and throughout the year.

\section{F. Participation:}

The Indigenous peoples of India live in extreme poverty and segregation. Introducing traditional farming techniques often exacerbates this, the rich often benefits, while the poor and the lowly are too left out. Sustainable agricultural interventions target the poorest of the poor and empower them to plan and speak for their the "voice", in order to promote the dialogue and democracy.

\section{RECOMMADATIONS}

FOR

\section{SUSTAINABLE OF AGRICULTURAL SECTOR}

- The development of existing production systems are as fallow (e.g .modified crop rotation, introduction of green ripeness, use of plant-specific varieties)

- The Improved environmental protection such as (e.g .erosion protection)

- The increased efficiency of the available resources (e.g. irrigation, use of technology, basic and advanced training)

- The Introduction of renewable business branches are (e.g. horticulture or aquaculture)

- The Introduction of new production of the equipment for the existing for the businesses (such as fruit trees to stabilize mountain fields 
and fish farming in rice fields)

- To improving the post-harvest programs (e.g. storage)

- The Increasing for the value of agricultural products and through continuous processing.

- The development of distribution channels (e.g. market access, transport)

- Access for to credit and other financial services.

- Risk (e.g. by international law, support for producer groups)

\section{CONCLUSION}

Under the changing of the agricultural landscape and agricultural technologies are require a transition from production for the sustainable farming with a profit margin. In this regard for, the pace of the adoption of conservation technology (RCTs) for Indian farmers is relatively satisfactory but, under the current circumstances, we are on the verge of halving agricultural savings. CA programs will lead to the sustainable farming and will be the goal of farming in the future.

The conditions for the development of sustainable agriculture farming are getting better for it. The new opportunities to open for the eyes of the farmers, the development workers, the researchers and policy makers. They now see to the power of importance of these processes are not only as a result of their direct to economic interests but also as the basis for further of consolidation and environmental sustainability, this is does not mean that the agricultural chemicals can be stopped and adopted for it. The research has also an important role to play it. The banks and financiers should think for the best way to the provides of benefits and loans for accessible to poor farmers and women, are in order to invest in the dry land farming. As agricultural conditions is to continue to change, and the key to agriculture is empowering for farmers and all other stakeholders in agricultural development, as well as the society as a whole has to learn and evaluate, adapt and work for effectively. In conclusion for managing small and farms to improve the productivity of profitability and sustainability for the farming system will go a long way to ensure that all farms.

\section{REFERENCES}

[1] Ajai, A. S. Arya, P. S. Dhinwa, S. K. Pathan and K.G.Raj (2009), Desertification/Land Degradation Status Mapping of India, Current Science, Vol. 97, No. 10.

[2] Government of India (2009), Report of the Thirteenth Finance Commission, New Delhi [3] Government of India (Ministry of Statistics and Programme Implementation) (2009), National Accounts Statistics 2009, New Delhi. 
[4] Kalirajan, K.P., G.Mythili and U.Sankar (2001), Accelerating Growth through Globalization of Indian Agriculture, Macmillan India,

[5] G. S. Sajja, M. Mustafa, K. Phasinam, K. Kaliyaperumal, R. J. M. Ventayen and T. Kassanuk, "Towards Application of Machine Learning in Classification and Prediction of Heart Disease," 2021 Second International Conference on Electronics and Sustainable Communication Systems (ICESC), 2021, pp. 1664-1669, doi:10.1109/ICESC51422.2021.9532940

[6] Veluri, R., Patra, I., Naved, M., Prasad, V., Arcinas, M., Beram, S., \& Raghuvanshi, A. (2021). Learning analytics using deep learning techniques for efficiently managing educational institutes. Materials Today: Proceedings. https://doi.org/10.1016/j.matpr.2021.11.4 $\underline{16}$

[7] C.M. Thakar, S.S. Parkhe, A. Jain et al., 3d Printing: Basic principles and applications, Materials Today: Proceedings, https://doi.org/10.1016/j.ma tpr.2021.06.272 